\title{
INTERCULTURAL COMPETENCE: APPLICATIONS IN MILITARY DOMAIN
}

\author{
Florentina-Lavinia MATEI \\ University of Bucharest, Romania \\ mateilavinia92@yahoo.com
}

Florentina-Ionela LINCĂ

University of Bucharest, Romania

linca.florentina@gmail.com

\begin{abstract}
This study investigates gender differences, differences by years of study, in terms of intercultural competence of military students, before an internship in international mobility. On the other hand, we have also shown that there is a causal relationship between intercultural attitudes and knowledge. The results of our study can be used in the realization of an intercultural competence training program.
\end{abstract}

KEYWORDS: attitudes, knowledge, intercultural competence, skills, students

\section{Introduction}

Intercultural competence is a topic of interest among those participating in international mobility, but it is not sufficiently explored or promoted in courses or training programs.

According to those mentioned by us in another study that also included military students, this competence can be the key to integration in various cultures (Matei, 2019; Matei \& Lincă, 2019).

Deardorff (2006) argued that this competence consists of three main elements: knowledge, skills, and attitudes.

If in other studies on the intercultural competence of military students (Matei \& Lincă, 2019), we presented the correlations between the elements of intercultural competence and the training students' needs regarding this competence, in this study, we will present gender differences, differences by years study of students before international mobility.
2. Research Methodology

2.1. Objective of Research

O1. Investigating gender differences in the skills, knowledge and attitudes of military students who will go on an international mobility internship;

O2. Investigating the differences in the skills, knowledge and attitudes of military students who will go on an international mobility internship depending on their years of study;

O3. Investigating the effects of skills and knowledge on the attitude of military students who will go on an internship in international mobility.

I1. It is assumed that there are gender differences in the skills, knowledge and attitudes of military students who will go on an international mobility internship.

I2. It is assumed that there are differences in the skills, knowledge and attitudes of military students who will go on an international mobility internship depending on the nation of study. 
I3. It is assumed that the skills and knowledge of military students who will go on an internship in international mobility influence their attitudes.

\subsection{Sample of Research}

The study was attended by 45 students from the "Nicolae Bălcescu" Land Forces Academy in Sibiu, 23 male and 22 female, aged between 19 and 23 years $(\mathrm{m}=20.1, \mathrm{SD}=1.5)($ Table no. 2$)$.

\subsection{Research Tool}

The tool used was the Intercultural Competence Assessment Questionnaire, it has three dimensions (Knowledge, Attitudes and Skills).

For this instrument the consistency index Apha Cronbach was calculated, obtaining the following values:

0.80 for the Knowledge Subscale (Table no. 1),

0.95 for the Attitudes Subscale (Table no. 1),

0.92 for the Skills Subscale (Table no. 1), which means that the items strongly correlate with the scale for the sample of this research.

Table no. 1

Cronbach Alpsh for the Intercultural Competence Assessment Questionnaire

\begin{tabular}{|c|c|}
\hline \multicolumn{2}{|c|}{ Cronbach's Alpha for the Knowledge Subscale } \\
\hline Cronbach's Alpha & $\mathrm{N}$ of Items \\
\hline, 800 & 6 \\
\hline \multicolumn{2}{|c|}{ Cronbach's Alpha for the Attitudes Subscale } \\
\hline Cronbach's Alpha & $\mathrm{N}$ of Items \\
\hline ,954 & 12 \\
\hline \multicolumn{2}{|c|}{ Cronbach's Alpha for the Skills Subscale } \\
\hline Cronbach's Alpha & $\mathrm{N}$ of Items \\
\hline ,929 & 10 \\
\hline
\end{tabular}

Table no. 2 shows the descriptive statistics of the values of the research variables. Thus, for the knowledge variable, the mean is 24.4 , the minimum value is 17 and the maximum is 31 . The attitude variable has a mean of
41 values, a minimum of 29 , and a maximum of 55, while the mean of the skills variable values is 30 , the minimum value is 20 , and the maximum value for the latter variable is 37 .

Table no. 2

Descriptive statistics

\begin{tabular}{lllllll}
\hline & age & gender & year.of.study & knowledge & attitudes & Abilities \\
\hline $\mathrm{N}$ & 45 & 45 & 45 & 45 & 45 & 45 \\
Missing & 0 & 0 & 0 & 0 & 0 & 0 \\
Mean & 20.1 & & 2.49 & 24.4 & 41.0 & 30.0 \\
Standard & 1.55 & 0.506 & 3.30 & 5.39 & 3.69 \\
deviation & & & 2 & 17.0 & 29.0 & 20.0 \\
Minimum & 19.0 & 3 & 31.0 & 55.0 & 37.0 \\
Maximum & 23.0 & & 3 & &
\end{tabular}


To achieve the objectives, hypotheses 1, 2 and 3 were tested.
As can be seen in the table below, all variables have a normal distribution of values, $p>0.05$.

Table no. 3

Shapiro-Wilk Test

\begin{tabular}{llll}
\hline & knowledge & attitudes & abilities \\
\hline $\mathrm{N}$ & 45 & 45 & 45 \\
Missing & 0 & 0 & 0 \\
Mean & 24.4 & 41.0 & 30.0 \\
Shapiro-Wilk p & 0.437 & 0.686 & 0.417 \\
\hline
\end{tabular}

In Table no. 4 it can be seen that Hypothesis 1 which assumes that there are gender differences in the skills, knowledge and attitudes of military students who will go on an international mobility internship is partially confirmed because for the variable skills the hypothesis is not confirmed, $p>0.05$, and for the variables knowledge and attitudes the hypothesis is confirmed, $\mathrm{t}=2.46$ and respectively $\mathrm{t}=4.41, \mathrm{p}<0.05$.

Table no. 4

Independent Samples T-Test-gender

\begin{tabular}{lllll}
\hline & & statistic & df & p \\
\hline knowledge & Student's t & 2.46 & 43.0 & 0.018 \\
attitudes & Student's t & 4.41 & 43.0 & $<.001$ \\
abilities & Student's t & 1.14 & 43.0 & 0.262 \\
\hline
\end{tabular}

Although gender differences in terms of intercultural competence in military students are not statistically significant, however, in the table below we can see that boys have a higher mean of scores than the mean of girls' scores in our sample, $\mathrm{m}=30,6$ and $\mathrm{m}=29.4$, respectively.

Table no. 5

Group Descriptives - gender

\begin{tabular}{lllllll}
\hline \multirow{2}{*}{ knowledge } & Group & N & Mean & Median & SD & SE \\
& masculin & 23 & 25.5 & 26.0 & 2.68 & 0.558 \\
\multirow{2}{*}{ attitudes } & feminin & 22 & 23.2 & 23.0 & 3.54 & 0.755 \\
& masculin & 23 & 44.0 & 43.0 & 4.22 & 0.879 \\
\multirow{3}{*}{ abilities } & feminin & 22 & 38.0 & 38.0 & 4.83 & 1.030 \\
& masculin & 23 & 30.6 & 31.0 & 2.87 & 0.599 \\
& feminin & 22 & 29.4 & 29.5 & 4.36 & 0.929 \\
\hline
\end{tabular}


Hypothesis I 2 it is assumed that there are differences in the skills, knowledge and attitudes of military students who will go on an internship of international mobility depending on the level of study is partially confirmed, because for the variable attitudes and skills the hypothesis is confirmed, $\mathrm{t}=2.25$ and $\mathrm{t}=2.58$, respectively, $\mathrm{p}<0.05$, and for the knowledge variable the hypothesis is not confirmed, $\mathrm{p}>0.05$ (Table no. 6).

Table no. 6

Independent Samples T-Test-years of study

\begin{tabular}{|c|c|c|c|c|c|c|c|c|c|}
\hline & & \multirow[b]{2}{*}{ statistic } & \multirow[b]{2}{*}{ df } & \multirow[b]{2}{*}{$\mathbf{p}$} & \multirow[b]{2}{*}{$\begin{array}{l}\text { Mean } \\
\text { difference }\end{array}$} & \multirow[b]{2}{*}{$\begin{array}{l}\text { SE } \\
\text { difference }\end{array}$} & \multicolumn{2}{|c|}{$\begin{array}{l}\text { 95\% Confidence } \\
\text { Interval }\end{array}$} & \multirow[b]{2}{*}{ Cohen's d } \\
\hline & & & & & & & Lower & Upper & \\
\hline knowledge & Student's t & 1.45 & 43.0 & 0.156 & 1.41 & 0.973 & -0.556 & 3.37 & 0.431 \\
\hline attitudes & Student's t & 2.25 & 43.0 & 0.029 & 3.47 & 1.539 & 0.363 & 6.57 & 0.672 \\
\hline abilities & Student's $t$ & 2.58 & 43.0 & 0.013 & 2.67 & 1.035 & 0.581 & 4.76 & 0.769 \\
\hline
\end{tabular}

Although the differences in terms of intercultural competence in military students by year of study are not statistically significant, however, in the table below we can see that second-year students have a higher mean of scores than the mean of third-year students, $\mathrm{m}=31.3$ and $\mathrm{m}=28.6$, respectively.

Table no. 7

Group Descriptives - years of study

\begin{tabular}{lllllll}
\hline & Group & N & Mean & Median & SD & SE \\
\hline knowledge & 2 & 23 & 25.0 & 25.0 & 2.46 & 0.513 \\
& 3 & 22 & 23.6 & 23.0 & 3.93 & 0.839 \\
attitudes & 2 & 23 & 42.7 & 44.0 & 5.48 & 1.142 \\
& 3 & 22 & 39.3 & 39.0 & 4.80 & 1.024 \\
abilities & 2 & 23 & 31.3 & 32.0 & 2.58 & 0.539 \\
& 3 & 22 & 28.6 & 28.0 & 4.20 & 0.896 \\
\hline
\end{tabular}

I3 It is assumed that the skills and knowledge of military students who will go on an internship in international mobility influence their attitudes is confirmed, $\mathrm{R}=0,42, \mathrm{p}<0.05$. 
Table no. 8

Model Fit Measures

\begin{tabular}{llllllll}
\hline & & \multicolumn{5}{c}{ Overall Model Test } \\
\cline { 4 - 7 } Model & $\mathbf{R}$ & $\mathbf{R}^{2}$ & $\mathbf{F}$ & $\mathbf{d f 1}$ & $\mathbf{d f 2}$ & $\mathbf{p}$ \\
\hline 1 & 0.421 & 0.178 & 4.53 & 2 & 42 & 0.016 \\
\hline
\end{tabular}

In the table below, we can see that only knowledge influences attitudes, not skills. A student may have a positive attitude and a lot of knowledge, but this does not mean that skills are developed at the same level as the other components of intercultural competence.

Table no. 9

Model Coefficients - attitudes

\begin{tabular}{lllll}
\hline Predictor & Estimate & SE & t & p \\
\hline Intercept & 20.269 & 7.126 & 2.84 & 0.007 \\
knowledge & 0.507 & 0.246 & 2.06 & 0.046 \\
abilities & 0.281 & 0.220 & 1.28 & 0.209 \\
\hline
\end{tabular}

Our results are in line with the results of other research.

Deardoff (2006) argues that skills, attitudes, and knowledge reflect observable behaviors of the individual learning to be interculturally competent. However, intercultural competence could only be limited to the ability to interact in multicultural contexts without discrimination or prejudice.

Last but not least, Günçavdı and Polat (2016), in a study in which 650 students had participated, found that there are statistically significant differences between female students and male students in terms of intercultural knowledge and attitudes.

\section{Conclusions}

In conclusion, all objectives have been achieved. Intercultural competence is the ability to interact in multicultural contexts without discrimination or prejudice. As we could see in this article, its components are not developed at the same level in the case of a person, as evidenced by the relationships between them, but also the existence of statistically insignificant differences in terms of the 3 components of intercultural competence. Although we did not have a large number of respondents, we can be drawn relevant and interesting conclusions for the area based on the results. 


\section{REFERENCES}

Deardorff, D.K. (2006). The Identification and Assessment of Intercultural Competence as a Student Outcome of Internalization. Journal of Studies in International Education, Vol. 10, Issue 3, 241-266, available at: http://www.mccc.edu/ lyncha/documents/DeardorffidentificationandassessmentofinterculturalcompetenceasanoutcomeofInternationalizat.pdf.

Günçavd1, G., \& Polat, S. (2016). Level of Intercultural Competence of International Students at Kocaeli University. Universal Journal of Educational Research, Vol. 4, Issue 12A, 39-45. DOI: 10.13189/ujer.2016.041306.

Matei, F.L. (2019). The intercultural competence of military students in the context of international mobility. Land Forces Academy Review, Vol. 24, Issue 2, 115-122, https://doi.org/10.2478/raft-2019-0013.

Matei, F.L., \& Lincă, F.I. (2019). Training needs of military students on intercultural competence. Land Forces Academy Review, Vol. 24, Issue 4, 291-296. https://doi.org/10.2478/raft-2019-0036. 